\title{
EFEK PEMBERIAN ARTEMISIN DAN MINYAK BUAH MERAH (Pandanus conoideus) TERHADAP PRODUKSI REACTIVE OXYGEN INTERMEDIATE SEL MAKROFAG PERITONEUM MENCIT DIINFEKSI MALARIA
}

\author{
Rahmad $^{\star 凶}$, Agustina Tri Endharti**, Loeki Enggar Fitri*
}

\begin{abstract}
Abstrak
Kerusakan jaringan hospes yang terinfeksi malaria dapat disebabkan oleh radikal bebas yang dihasilkan akibat respons imun yang berlebihan dan mekanisme kerja artemisin. Kandungan beta-karoten dan tokoferol yang tinggi dalam minyak buah merah berfungsi sebagai antioksidan dan imunostimulator. Penelitian ini bertujuan mengetahui pengaruh terapi kombinasi artemisin dan minyak buah merah terhadap pembentukan reactive oxygen intermediate (ROI) oleh makrofag. Sebagai model malaria digunakan Plasmodium berghei yang diinfeksikan ke mencit Balb/C secara intraperitoneal. Sampel terdiri dari kelompok mencit normal, mencit yang diinfeksi $P$. berghei (kontrol positif), mencit yang diinfeksi $P$. berghei dan diterapi artemisin $0,0364 \mathrm{mg} / \mathrm{gBB}$ peroral, mencit yang diinfeksi $P$. berghei dan mendapat artemisin $0,0364 \mathrm{mg} / \mathrm{gBB}$ serta minyak buah merah (dosis $16,5 \mu \mathrm{L} /$ mencit, $49 \mu \mathrm{L} /$ mencit, dan $97,5 \mu \mathrm{L} /$ mencit). Didapatkan penurunan parasitemia pada kelompok mencit yang diterapi dengan artemisin serta kombinasi artemisin dan minyak buah merah pada hari ke-3. Keadaan ini diikuti dengan rendahnya jumlah sel makrofag yang memproduksi $\mathrm{ROI}$ yaitu pada kelompok yang mendapat artemisin saja maupun kombinasinya dengan minyak buah merah dosis 16,5 $\mu \mathrm{L} /$ mencit, dan dosis $49 \mu \mathrm{L} /$ mencit dibanding kelompok kontrol positif (berturut-turut $p=0,003 ; p=$ $0,007 ; p=0,003)$, kecuali pada mencit dosis $97,5 \mu \mathrm{L}$ yang menunjukkan setara dengan kontrol positif $(p=$ 0,822 ). Pada hari ke-5, jumlah sel makrofag yang memproduksi ROI lebih rendah pada kelompok kombinasi artemisin dan minyak buah merah dosis $49 \mu \mathrm{L} /$ mencit, dan dosis $97,5 \mu \mathrm{L} /$ mencit dibandingkan dengan kelompok artemisin saja dan kontrol positif $(p=0,000)$. Disimpulkan bahwa pada infeksi malaria yang diberi terapi artemisin, buah merah dosis tinggi diperlukan sebagai imunostimulator pada fase akut dan sebagai antioksidan pada fase kronis.
\end{abstract}

Kata kunci: artemisinin, makrofag, malaria, reactive oxygen intermediate, buah merah (Pandanus conoideus)

\section{THE EFFECT OF ARTEMISIN AND RED FRUIT OIL (Pandanus conoideus) TO THE PRODUCTION OF REACTIVE OXYGEN INTERMEDIATE BY PERITONEAL MACROPHAGE IN MALARIA INFECTED MICE}

\begin{abstract}
Abundance immune response to malaria that involves free radical can cause damage in the host tissue as well as mechanism of artemisin. Red fruit oil consisted of high amount of beta-carotene and tocopherol that has multiple roles as antioxidant and immunostimulator. The aimed of this study was to analyze the influence of combination therapy of artemisin and red fruit oil to the forming of reactive oxygen intermediate (ROI) by the macrophage. Plasmodium berghei was used for malaria model, which infected to Balb/c strain mice through intraperitoneal. The samples were normal mice (negative control group), mice that were infected by $P$. berghei (positive control group), mice were infected by $P$. berghei and treated with artemisin $0,0364 \mathrm{mg} / \mathrm{gBW}$, mice were infected by $P$. berghei and treated with combination of artemisin $0,0364 \mathrm{mg} / \mathrm{gBW}$ and red fruit oil dose $16,5 \mu \mathrm{L} / \mathrm{mice}$, dose $49 \mathrm{~L} / \mathrm{mice}$ and dose $97,5 \mu \mathrm{L} / \mathrm{mice}$ respectively. The treated groups had a lower number of parasitemia than positive control group on day-3. The decline of parasite density was followed by the low numbers of macrophage cell that produce ROI in red fruit oil dose 16,5 $\mu \mathrm{L} / \mathrm{mice}$, dose 49 $\mu \mathrm{L} /$ mice compared to positive control $(p=0.003 ; p=0.007 ; p=0.003$, respectively) except on the group that had artemisin and dose $97,5 \mu \mathrm{L} / \mathrm{mice}$ of red fruit oil, which had increased number of macrophage that produce ROI similar to positive group $(p=0.822)$. The number of macrophage cells that produce ROI on group that treated with combination therapy artemisin and red fruit oil dose $49 \mu \mathrm{L} /$ mice and $97,5 \mu \mathrm{L} / \mathrm{mice}$ were lower compare to artemisin only group and control positive group $(p=0.000)$ on day- 5 . In conclusion, that in malaria infection a high dosage of red fruit oil was needed to be a imunostimulators on the acute phase and to be antioxidant on the chronic phase.
\end{abstract}

$凶$ E-mail: rahmadanwar19833@gmail.com 
Keywords: artemisin, macrophage, malaria, reactive oxygen intermediate, red fruit oil (Pandanus conoideus).

* Departemen IImu Kedokteran Fisik dan Rehabilitasi, Fakultas Kedokteran UB-RSSA Malang

** Departemen Parasitologi, Fakultas Kedokteran Universitas Brawijaya Malang

\section{Pendahuluan}

Patologi dan berbagai manifestasi klinis dari penyakit malaria dapat dijelaskan melalui berbagai teori imunologis, teori mekanik atau keduanya. Penelitian terakhir menunjukkan adanya keterlibatan radikal bebas dalam patologi malaria. Penelitian sebelumnya menunjukkan bahwa pada mencit yang diinfeksi Plasmodium berghei terdapat peningkatan aktifitas radikal bebas melalui peroksidasi lemak dan berhubungan dengan kelainan patologi. Hal ini dapat dilihat dari peningkatan kadar malonyldialdehide (MDA) dan secara tidak langsung melalui penurunan kadar superoxyde dismutase (SOD) yang berfungsi sebagai scavenger. ${ }^{1}$

Respons imun hospes dalam rangka melawan keberadaan Plasmodium merupakan proses yang kompleks dan spesifik tergantung spesiesnya. Respons imun hospes melibatkan aktivasi makrofag, limfosit $T$, limfosit B, disertai pelepasan sitokin, dan melibatkan berbagai sel imun yang lain. Adanya parasit dalam eritrosit akan menstimulasi sel-sel fagosit untuk melepaskan radikal bebas atau reactive oxygen species (ROS) yang menyebabkan stres oksidatif yang sebenarnya bertujuan mengeliminasi parasit atau eritrosit berparasit (pRBC). Namun karenan sifatnya yang tidak spesifik dapat menyebabkan penghancuran terhadap eritrosit normal (RBC) atau hemolisis. Selain itu, ROS dapat menyerang endotel yang dapat menyebabkan kerusakan pada berbagai jaringan. Dapat dikatakan perusakan oksidatif oleh radikal bebas diduga mengarah pada terjadinya berbagai kelainan patologis pada penderita malaria seperti thrombositopeni dan kerusakan endotel hingga malaria serebral. ${ }^{2}$

Artemisin bekerja sebagai antimalaria karena memiliki jembatan endoperixides. Obat ini bekerja melalui pembentukan radikal bebas dengan memutus jembatan peroksida tersebut dengan bantuan haem. Radikal bebas yang terbentuk akan mengalkilasi berbagai protein parasit, bereaksi dengan translationally controlled tumor protein (TCTP), menginhibisi sarcoplasmic/endoplasmic-reticulum $\mathrm{Ca}^{2+-}$ ATPase (SERCA) dan Plasmodium falciparum cysteine proteases. Juga ikatan haem dan artemisin (haemarts) menghambat biosintesis haemozoin. ${ }^{3}$ Dalam penelitian lain menunjukkan bahwa pemberian artemisin juga berperan dalam meningkatkan stres oksidatif, ditandai dengan peningkatan kadar lipid peroksidase serta menurunnya kadar glutathone pada ibu hamil yang terinfeksi malaria. ${ }^{4}$

Normalnya, efek yang merugikan dari radikal bebas ini dapat dihambat oleh adanya sistem pertahanan enzimatik di dalam sel sendiri. Di dalam tubuh, terdapat berbagai macam sistem proteksi terhadap radikal bebas, yaitu terdiri dari sistem enzimatik dan nonenzimatik. Contoh sistem enzimatik adalah superoxyde dismutase (SOD), katalase, dan gluthation peroxydase. Contoh dari sistem nonenzimatik adalah vitamin larut lemak (betakaroten, vitamin $A$, vitamin E) serta vitamin larut air (vitamin $C$, gugus thiol). Superoxyde dismutase sebagai antioksidan dapat bereaksi atau mencegah pembentukan radikal bebas dari molekul lain. Dalam batas-batas tertentu, kemampuan sel untuk membentuk SOD meningkat dengan adanya rangsangan radikal bebas. ${ }^{5}$ Sebagai usaha untuk menjaga integritas jaringan, maka harus ada 
keseimbangan antara produksi radikal bebas dengan sistem antioksidan. Pada saat potensi oksidan dalam jumlah tinggi maka akan terjadi efek oksidan yang luas sehingga dapat terjadi kerusakan irreversible. .Konsep ini mendasari suatu upaya pencegahan penyakit atau pengobatan kerusakan jaringan atau organ akibat radikal bebas. Dengan demikian, perlu dipikirkan penggunaan suplemen antioksidan eksogen pada infeksi malaria sebagai scavenger atau sebagai pertahanan sel untuk meredam dampak negatif dari radikal bebas tersebut. Salah contoh jenis antioksidan yang sering diteliti dalam fungsinya sebagai pencegahan penyakit kronis adalah beta karoten atau karotenoid. Beta karoten memiliki fungsi antioksidan baik secara in vitro maupun dalam model hewan coba. ${ }^{6}$

Buah merah, Pandanus conoideus, mengandung senyawa antioksidan dalam jumlah yang tinggi. Buah merah mengandung zat-zat aktif seperti betakaroten, tokoferol, dan sejumlah asam lemak esensial. Buah endemik dari Irian ini telah digunakan secara tradisional oleh masyarakat setempat sejak nenek moyang antara lain untuk bahan pangan, obat cacing, penyakit kulit, dan penghambat kebutaan. ${ }^{7}$ Buah merah sudah dicoba pada berbagai penyakit seperti kanker, HIV dan lain-lain. ${ }^{8}$ Namun penggunaan buah merah pada infeksi malaria belum pernah diteliti. Penelitian ini berguna untuk mengetahui efek pemberian minyak buah merah sebagai terapi ajuvan artemisinin pada penderita malaria. Penulis ingin meneliti efek penambahan buah merah tersebut terhadap produksi radikal bebas oleh makrofag.

\section{Bahan dan Metode}

\section{Desain Penelitian}

Desain penelitian adalah post test-only control group menggunakan mencit Balb/C yang diinfeksi Plasmodium bergehei sebagai model malaria. Sampel terdiri dari 6 kelompok yaitu kelompok 1 (kelompok mencit normal atau kontrol negatif), kelompok 2 (kelompok mencit yang diinfeksi Plasmodium berghei atau kontrol positif), kelompok 3 (kelompok mencit yang diinfeksi dan mendapat terapi artemisin 0,0364 $\mathrm{mg} / \mathrm{gBB}$ ), dan kelompok 4 (kelompok mencit yang diinfeksi dan mendapat terapi artemisin 0,0364 mg/gBB serta minyak buah merah dosis $16,5 \mu \mathrm{L} /$ hari), kelompok 5 (kelompok mencit yang diinfeksi dan mendapat terapi artemisin 0,364 mg/gBB serta minyak buah merah dosis $49 \mu \mathrm{L} /$ hari), kelompok 6 (kelompok mencit yang diinfeksi dan mendapat terapi artemisin 0,0364 mg/gBB serta minyak buah merah dosis dosis 97,5 $\mu \mathrm{L} /$ hari). Pada masing-masing kelompok dilakukan pengulangan sebanyak 3 (tiga) kali. Pemeriksaan sekresi reactive oxygen intermediate (ROI) oleh sel makrofag dilakukan menggunakan Nitroblue Tetrazolium (NBT) reduction assay. Pemeriksaan parasitemia dan $\mathrm{ROI}$ oleh sel makrofag dilakukan pada hari ke-3 dan ke-5 setelah pemberian terapi.

\section{Model Hewan Coba}

Hewan coba yang digunakan adalah mencit jantan Balb/c dengan berat 30 - $40 \mathrm{~g}$, sehat, aktif, dan memiliki bulu putih. Hewan coba didapatkan dari LPPT Universitas Gadjah Mada. Mencit diletakkan di dalam kandang ukuran $30 \times 30 \mathrm{~cm}$ berisikan 4 mencit tiap kandang. Mencit diberi makan dan minum standar tiap harinya. Perlakuan pada hewan coba sudah disetujui oleh Komite Etik Fakultas Kedokteran Universitas Brawijaya. Sebelum diberikan perlakuan percobaan, hewan coba dikandangkan tanpa perlakuan unuk aklimatisasi selama 7 hari.

\section{Persiapan dan Inokulasi Plasmodium Berghei}

Plasmodium berghei strain ANKA didapatkan dari Laboratorium Biomedik 
Universitas Brawijaya. Pelet eritrosit terinfeksi $P$. berghei yang disimpan di tangki nitrogen cair dengan suhu $-135^{\circ} \mathrm{C}$, dicairkan di dalam refrigerator dan disentrifugasi pada 2000 rpm selama 5 menit. Pelet kemudian dicuci dua kali dalam medium RPMI dan diencerkan untuk kebutuhan inokulasi secara intraperitoneal (ip) dengan jumlah $10^{7}$ parasit pada $0,2 \mathrm{ml}$ darah per mencit. ${ }^{9}$ Parasitemia kemudian diperiksa menggunakan hapusan darah tipis yang diwarnai dengan giemsa. Derajat parasitemia diukur dengan cara menghitung eritrosit yang terinfeksi per 100 eritrosit.

\section{Pemberian Terapi pada Hewan Coba}

Ekstrak minyak buah merah dengan dosis 16,5 $\mu \mathrm{L} /$ mencit, $49 \mu \mathrm{L} /$ mencit, dan 97,5 $\mu \mathrm{L} /$ mencit diberikan pada hewan coba secara per oral menggunakan sonde. Dosis artemisin yang digunakan adalah 0,0364 $\mathrm{mg} / \mathrm{grBB}$ setelah sebelumnya dilarutkan dalam 10\% DMSO (Dimethyl Sulfoxide) dan $90 \%$ salin dan diberikan secara per oral. Pemberian terapi pada hewan coba dimulai 48 jam setelah inokulasi $P$. berghei serta diberikan satu kali sehari selama 5 hari. ${ }^{10}$

\section{Isolasi dan Kultur Sel Makrofag Peritoneum Mencit}

Setelah mencit dieuthanasia, dinding abdomen disterilkan dengan alkohol $70 \%$. Dinding abdomen dibuka sehingga tinggal peritoneum yang menutupi isi abdomen. Untuk mendapatkan sel makrofag peritoneum, medium $\mathrm{M}+$ diinjeksikan sebanyak $10 \mathrm{~mL}$ dengan spuit. Medium dalam abdomen digoyang selama 5 menit, kemudian medium diambil kembali dengan spuit. Medium $\mathrm{M}+$ yang mengandung sel makrofag dipindahkan ke dalam tabung falcon $15 \mathrm{ml}$. Tabung diletakkan dalam termos berisi es $\pm 4{ }^{\circ} \mathrm{C}$ selama 30 menit agar makrofag tidak aktif, kemudian disentrifus 3000 rpm 10 menit. Supernatan yang didapat dibuang, pellet yang tersisa dalam tabung dicampur dengan eritrosit lisis buffer sebanyak $1 \mathrm{ml}$ untuk melisiskan eritrosit. Eritrosit dilisiskan untuk mendapat makrofag yang lebih murni. Isolat makrofag divortex dan didiamkan selama 10 menit. Isolat makrofag disentrifus $3000 \mathrm{rpm}$ selama 5 menit, kemudian supernatan dibuang. Ditambahkan medium komplit ke dalam pellet dan dipipeting. Lalu, isolat makrofag dituang ke dalam well plate 24 kemudian diinkubasi pada suhu $37^{\circ} \mathrm{C}$ selama 2 jam agar makrofag melekat sehingga makrofag dan sel-sel lain terpisah. Setelah 2 jam, medium dipipetting dan dibuang sehingga sel-sel selain makrofag terbuang bersama medium tersebut, sedangkan makrofag tidak ikut terbuang karena telah melekat pada cover slip. Ditambahkan kembali medium komplit sebanyak $0,5 \mathrm{ml}$ ke dalam well plate. Kemudian makrofag diinkubasi lagi pada $37^{\circ} \mathrm{C}$ selama 24 jam. ${ }^{11}$

\section{Reactive Oxygen Intermediate Assay}

Pengukuran ROI yang dihasilkan oleh sel makrofag menggunakan metode Nitroblue Tetrazolium (NBT) Reduction Assay. Pada uji ini Phorbol 12-Myristate 13Acetate (PMA) akan menstimulasi makrofag untuk mensekresi ROI, dan adanya ROI (anion superoksida, O2-) akan menyebabkan NBT tereduksi sehingga membentuk presipitat formazan yang tidak terlarut. ${ }^{12}$ Dipersiapkan biakan sel makrofag di atas cover slip dalam sumuran plate 24 yang sudah mendapat perlakuan. Dilakukan pencucian dengan menggunakan PBS sebanyak 2 kali. Pada well plate ditambahkan PMA $125 \mathrm{ng} / \mathrm{mL}$ sebanyak 50 $\mu \mathrm{L}$, Nitroblue tetrazolium $1 \mathrm{mg} / \mathrm{mL}$ sebanyak $400 \mu \mathrm{L}$, dan HBSS (Hank's Balance Salt Solution) sebanyak $50 \mu \mathrm{L}$. Diinkubasikan kedalam inkubator $37^{\circ} \mathrm{C}, 5 \%$ $\mathrm{CO}_{2}$, selama satu jam. Supernatan dibuang dan sel makrofag dicuci dengan PBS (phospate-buffered saline) sebanyak tiga kali. Difiksasi dengan metanol (30 detik, 
suhu ruang). Metanol diambil dari well plate, kemudian ditambahkan neutral red solution $2 \%$ selama 30 menit. Terakhir dicuci dengan air mengalir dan kemudian dikeringkan. Setelah kering, cover slip yang berisi sel makrofag ditempelkan di atas gelas objek dengan menggunakan perekat preparat, setelah menempel bagian atasnya ditutup lagi dengan menggunakan gelas tutup. Aktivitas makrofag untuk mensekresi ROI diukur dengan menghitung persentase makrofag yang mensekresi ROI yaitu yang menunjukkan pembentukan formazan (warna gelap), dihitung 100 makrofag yang terlihat di bawah mikroskop cahaya. ${ }^{13}$

\section{Hasil}

Jumlah Sel Makrofag yang Memproduksi Reactive Oxygen Intermediate

Untuk mengetahui pengaruh pemberian artemisin dan minyak buah merah terhadap produksi radikal bebas pada infeksi malaria dilakukan pemeriksaan produksi $\mathrm{ROI}$ oleh sel makrofag peritoneum pada hari ke-3 dan ke-5. Pada Gambar 1 ditunjukkan jumlah sel makrofag yang memproduksi ROI, dan Gambar 2 memperlihatkan foto sel makrofag hasil pengecatan khusus $\mathrm{ROI}$.

Pada hari ke-3 jumlah sel makrofag yang memproduksi $\mathrm{ROI}$ lebih rendah dan berbeda bermakna pada kelompok 3,4 , dan 5 dibanding dengan kelompok 2 atau kelompok kontrol positif $(p=0,003 ; p=$ 0,$007 ; p=0,003$, one way Anova). Jumlah sel makrofag yang memproduksi ROI lebih tinggi dan berbeda bermakna pada kelompok 6 dibanding kelompok 3,4 , dan 5 $(p=0,000 ; p=0,000 ; p=0,000$, one way Anova), tetapi tidak berbeda bermakna dibanding dengan kempok kontrol positif ( $p=$ 0,822 , one way Anova). Jumlah sel makrofag yang memproduksi ROI tidak berbeda bermakna di antara kelompok 3, 4, dan 5 ( $p>0,05$, one way Anova). Pada hari ke-5, jumlah sel makrofag yang memproduksi ROI pada kelompok 5 dan 6 lebih rendah dan berbeda bermakna dibanding kelompok 3 atau kelompok dengan terapi artemisin saja $(p=0,000 ; p=$ 0,000, one way Anova).

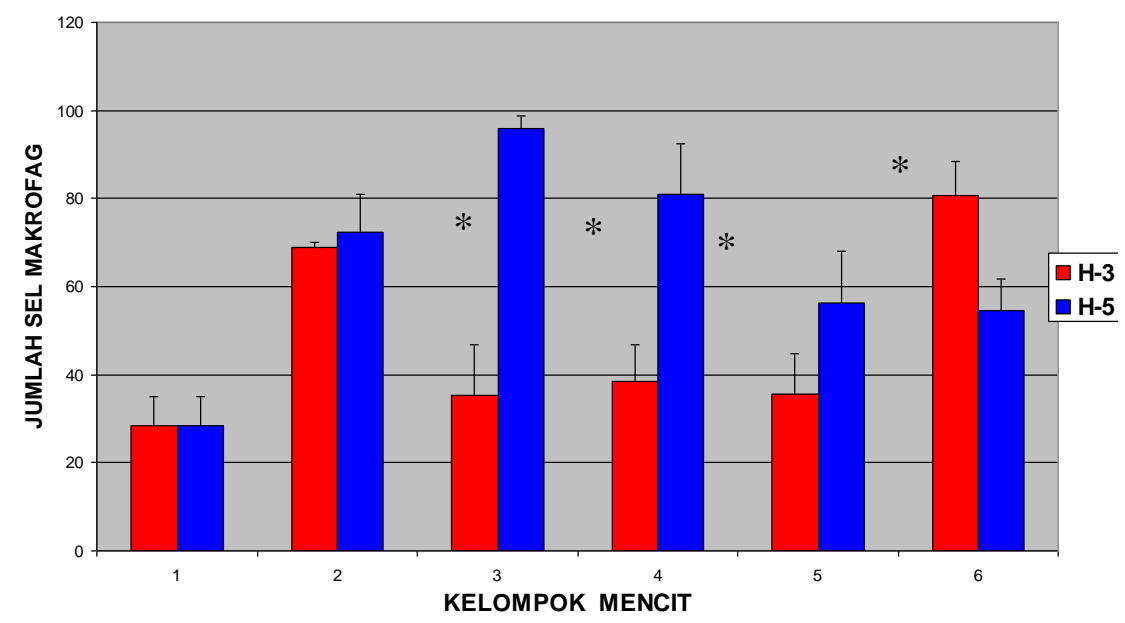

Gambar 1. Diagram rata-rata jumlah ROI/100 sel makrofag pada hari ke-3 dan ke-5.

Keterangan: 1: Kelompok kontrol negatif; 2: Kelompok kontrol positif; 3: Kelompok dengan terapi artemisin; 4: Kelompok dengan terapi artemisin dan minyak buah merah dosis $16,5 \mu \mathrm{L} ; 5$ : Kelompok dengan terapi artemisin dan minyak buah merah dosis $49 \mu \mathrm{L}$; 6: Kelompok dengan terapi artemisin dan minyak buah merah dosis $97,5 \mu \mathrm{L}$. Notasi asterix ( $\left.{ }^{*}\right)$ menunjukkan perbedaan yang signifikan dengan kelompok kontrol positif $(p<0,05)$. 


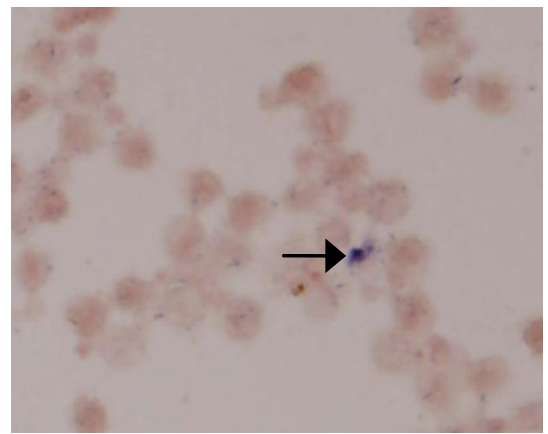

(A)

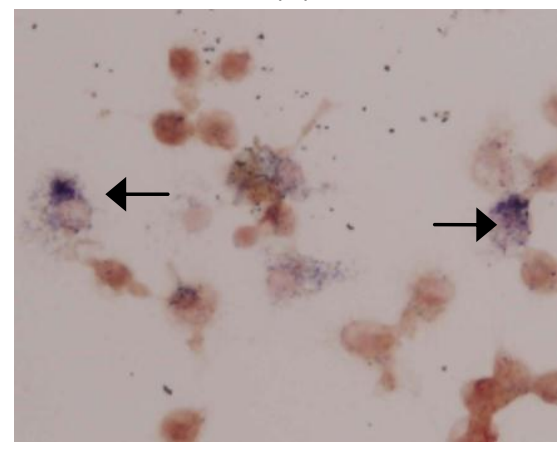

(C)

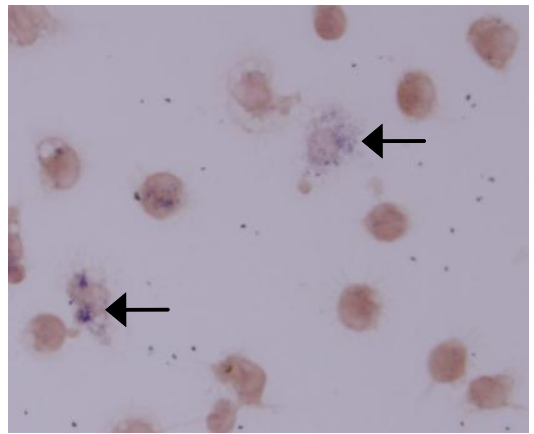

(B)

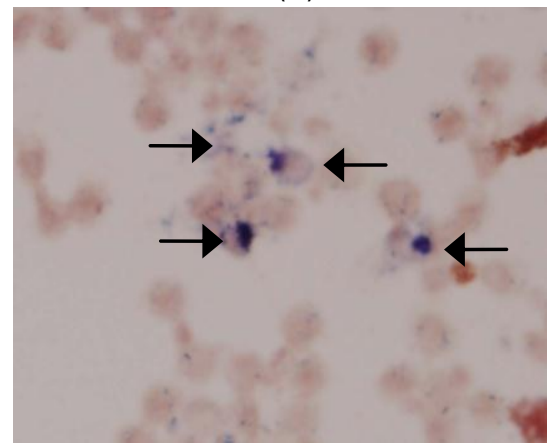

(D)

Gambar 2. Produksi ROI pada kelompok kontrol positif dan kelompok perlakuan.

Tanda panah menunjukkan ROI yang dihasilkan oleh sel makrofag peritoneum. (A) Kelompok kontrol positif; (B) Kelompok yang diterapi artemisin, (C) Kelompok yang diterapi artemisin dan minyak buah merah dosis $16,5 \mu \mathrm{L}$, (D) Kelompok yang diterapi artemisin dan minyak buah merah dosis $49 \mu \mathrm{L}$.

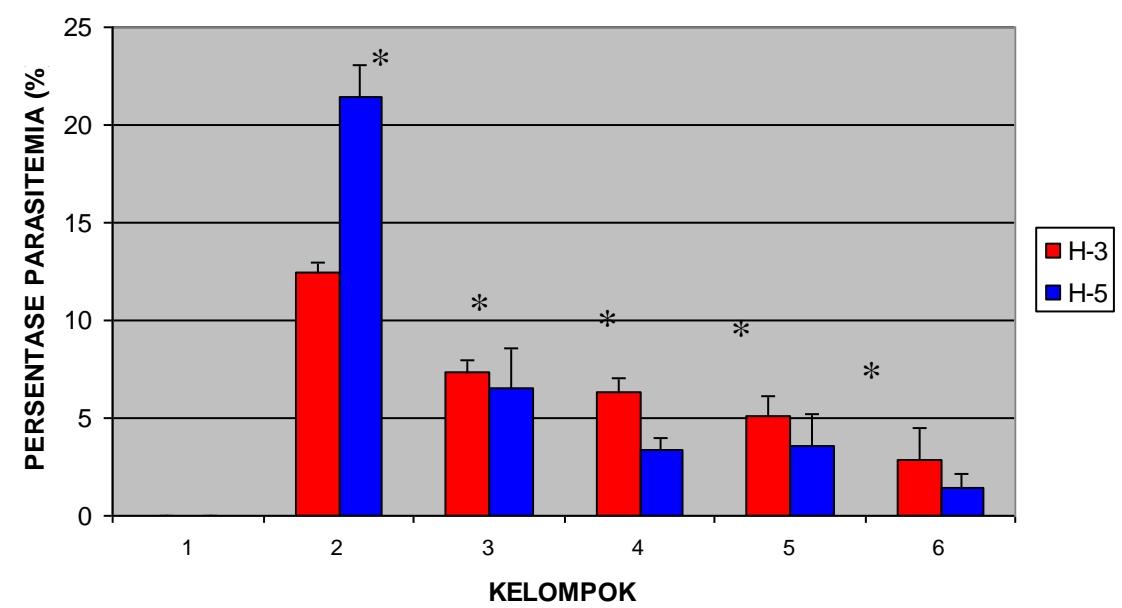

Gambar 3. Diagram persentase parasitemia pada hari ke-3 dan ke-5.

Keterangan: 1: Kelompok kontrol negatif; 2: Kelompok kontrol positif; 3: Kelompok dengan terapi artemisin; 4: Kelompok dengan terapi artemisin dan minyak buah merah dosis $16,5 \mu \mathrm{L} ; 5$ : Kelompok dengan terapi artemisin dan minyak buah merah dosis $49 \mu \mathrm{L}$; 6: Kelompok dengan terapi artemisin dan minyak buah merah dosis $97,5 \mu \mathrm{L}$. Notasi asterix $\left(^{*}\right)$ menunjukkan perbedaan yang bermakna dengan kelompok kontrol positif $(p<0,05)$.

\section{Persentase Parasitemia}

Produksi ROI oleh sel makrofag merupakan salah satu respons imun terhadap infeksi malaria. Untuk mensinkronkan pengaruh pemberian terapi artemisin dan minyak buah merah dengan beratnya infeksi terhadap produksi ROI dilakukan penghitungan

persentase 
parasitemia. Hasil penghitungan ditunjukkan pada Gambar 3.

Dapat dilihat bahwa kelompok yang diberi terapi, baik dengan artemisinin (kelompok 3) maupun artemisinin dengan adjuvant minyak buah merah menunjukkan persentase parasitemia lebih rendah dibanding kontrol positif ( $p=0,000$, one way Anova). Turunnya persentase parasitemia dengan penambahan dosis ajuvan minyak buah merah yang diberikan pada hari ke-5 menunjukkan korelasi yang tidak bermakna $(p=0,073 ; r=-0,623$, Pearson correlation test), tetapi pada hari ke-3 menunjukkan korelasi yang bermakna $(p=0,007 ; r=$ $-0,821$, Pearson correlation).

\section{Pembahasan}

Artemisin dapat menurunkan derajat parasitemia dengan cepat. Persentase parasitemia pada mencit yang diterapi dengan artemisin (dengan atau tanpa kombinasi minyak buah merah) lebih rendah dan berbeda bermakna dibanding kelompok kontrol positif yang tidak mendapat terapi pada hari ketiga dan hari kelima $(p=0,000$, $p=0,000$, one way Anova). Walaupun dapat menurunkan derajat parasitemia secara signifikan, masih didapatkan bentuk parasit malaria pada semua kelompok mencit yang mendapat terapi pada hari kelima. Hal ini dimungkinkan karena artemisin diberikan secara tunggal (monoterapi). Terapi antimalaria yang direkomendasikan oleh World Health Organization untuk malaria tanpa komplikasi adalah artemisinin-based combination treatments (ACT); yaitu kombinasi antara derivat artemisinin dan antimalaria lainnya yang secara struktural lebih lambat eliminasinya dalam sirkulasi. Tingkat kesembuhan paling tidak harus mencapai $90 \%$ dan $>95 \%$ jika dimonitor pada $\geq 28$ hari setelah pengobatan. ACT menjamin kesembuhan yang tepat dan cepat dan menggantikan pemberian artemisinin monoterapi yang memang sering mengalami kegagalan dalam menurunkan parasitemia. ${ }^{14}$ Dalam sebuah uji klinis, didapatkan juga artemisin dapat menghancurkan 95\% parasit malaria dalam waktu dua puluh jam. Demam yang menyertai infeksi malaria hilang dalam delapan jam setelah pemberian artemisin. ${ }^{15}$ Masih didapatkannya parasit pada hari kelima kemungkinan juga karena pengaruh kombinasi artemisin dan minyak buah merah. Pemberian artesunate bersama minyak buah merah mungkin menurunkan absorbsi artesunate karena obat ini bersifat water soluble.

Dari penelitian didapatkan hasil bahwa jumlah sel makrofag yang memproduksi ROI pada kelompok kontrol positif lebih tinggi dan berbeda bermakna dibanding kelompok mencit sehat pada hari ketiga dan hari kelima ( $p=0,000 ; p=0,000$, one way Anova). Hal ini menunjukan adanya respons imun terhadap infeksi malaria. Radikal bebas dihasilkan oleh makrofag sebagai respons terhadap parasit. Makrofag menghasilkan oksigen reaktif dan nitrogen reaktif yang bersifat mikrobisidal yang dapat membunuh parasit melalui proses oksidasi. ${ }^{16}$

Jumlah radikal $\mathrm{H}_{2} \mathrm{O}_{2}$ dan $\mathrm{O}_{2}{ }^{-}$yang dihasilkan oleh eritrosit yang terinfeksi Plasmodium falciparum dua kali lebih banyak dibanding dengan yang dihasilkan oleh eritrosit normal. Didapatkan total lipid peroksidase serum yang tinggi pada penderita malaria dibanding orang sehat. Dilaporkan juga lipid peroksidase dalam serum penderita malaria Plasmodium falciparum lebih tinggi dibanding penderita malaria Plasmodium vivax. Penurunan antioksidan (superoxide dismutase, serum $\alpha$ tocopherol, dan serum iron) juga teramati ketika terjadi peningkatan stres oksidatif pada penderita malaria yang tidak diobati. Penurunan maksimum aktivitas SOD eritrosit ditemukan pada infeksi $P$. vivax dibandingkan infeksi $P$. falciparum. ${ }^{17}$ 
Penelitian lain mengungkapkan bahwa ekspresi gen yang mensintesis NO mengalami up-regulation pada limpa mencit yang diinfeksi malaria. Makrofag peritoneum dan limpa memproduksi NO pada level yang tinggi $\left(24 \mu \mathrm{M}\right.$ per $10^{5}$ makrofag peritoneum dan $15 \mu \mathrm{M}$ per $10^{5}$ makrofag limpa sebagai respons terhadap lipopolisakarida. ${ }^{18}$ Masuknya parasit malaria ke dalam makrofag disertai dengan peningkatan metabolisme berupa peningkatan respirasi (respiratory burst). Dalam peristiwa lonjakan respirasi akan terjadi kenaikan konsumsi oksigen, serta pembentukan radikal bebas. Dalam membran makrofag terdapat rantai transfer elektron yang mengandung NADPH oksidase. NADPH ini aktif apabila terjadi kontak antara membran makrofag dengan partikel, maka akan terjadi transfer elektron. Transfer elektron dari oksigen akan mengakibatkan reduksi sebuah elektron dari oksigen tersebut membentuk anion superoksida. ${ }^{19}$

Pada hari ketiga, jumlah sel makrofag yang memproduksi ROI pada kelompok yang mendapat terapi artemisin dengan atau tanpa kombinasi minyak buah merah (kecuali kelompok F) lebih rendah dan berbeda bermakna dibanding kelompok kontrol positif $(p=0,003 ; p=0,007 ; p=$ 0,003 , one way Anova). Artemisin dengan cepat menurunkan kepadatan parasit dalam darah. Keadaan ini selanjutnya akan menurunkan rangsangan pada sistem imun karena sedikitnya antigen yang beredar. Sehingga respons imun terhadap infeksi malaria berkurang atau berhenti. Demikian juga pembentukan ROI oleh makrofag akan berkurang atau berhenti apabila tidak ada rangsangan. Tetapi tidak ada perbedaan jumlah makrofag yang menproduksi ROI diantara kelompok mencit yang mendapat artemisin saja dengan kelompok yang mendapat artemisin dan buah merah dosis $16,5 \mu \mathrm{L} /$ hari, dan kelompok mencit yang mendapat artemisin dan buah merah dosis
$49 \mu \mathrm{L} /$ hari. Kemungkinan hal ini karena masih adanya parasit walaupun dengan derajat parasitemia yang lebih rendah dibanding kontrol positif sehingga rangsangan terhadap sistem imun masih terjadi. Kulkarni et al., (2003) melaporkan bahwa tiga hari setelah pengobatan dengan klorokuin terjadi penurunan total lipid peroksidase serum dibandingkan dengan penderita yang tidak mendapat terapi. ${ }^{17} \mathrm{Hal}$ ini diduga terkait dengan pengurangan produksi reactive oxygen species oleh parasit malaria karena pembersihan parasit dari darah.

Pada penelitian ini dilakukan penambahan buah merah sebagai ajuvan artemisinin karena buah merah mengandung antioksidan yang tinggi seperti karotenoid, tokoferol, betakaroten, dan alfatokoferol. ${ }^{20}$ Karoten dapat meredam aktifitas radikal bebas yang dihasilkan parasit dan sistem imun, menghambat peroksidasi membran lipid, sehingga membantu mencegah kerusakan membran sel serta mengurangi kerusakan jaringan sekitar. ${ }^{21}$ Tokoferol dalam buah merah juga berperan sebagai pemutus reaksi radikal bebas pada jaringan dan plasma terutama pada jaringan dengan tekanan parsial oksigen yang tinggi seperti membran traktrus respiratorius dan retina. Tokoferol dapat mencegah peroksidasi lipid dan pengrusakan membran sel serta menjaga stabilisas membran, sehingga dapat mengurangi kerusakan jaringan akibat radikal bebas. ${ }^{22}$ Antioksidan eksogen seperti vitamin $A$, vitamin $C$, vitamin $E, N A C$ dan riboflavin dapat digunakan sebagai adjunctive/supporting terapi pada infeksi malaria yang akut dan kronis. Antioksidan tersebut dapat mempercepat kesembuhan, penurunan aktivitas radikal bebas dan peningkatan imunitas. ${ }^{23}$

Pada hari ketiga, jumlah sel makrofag yang memproduksi $\mathrm{ROI}$ mencit kelompok yang diterapi dengan artemisin dan minyak buah merah dosis $97,5 \mu /$ hari lebih tinggi 
dan berbeda bermakna dibanding kelompok yang mendapat terapi artemisin dan minyak buah merah dosis16,5 $\mu \mathrm{L}$ dan $49 \mu \mathrm{L}$. Produksi ROI pada mencit kelompok ini tidak berbeda dibanding dengan kelompok kontrol positif. Hal ini menunjukan dosis tertentu yang tinggi diperlukan agar buah merah memiliki efek imunostimulator terutama pada fase akut untuk mengeliminasi parasit.

Pada hari kelima, jumlah sel makrofag yang memproduksi ROI pada kelompok yang mendapat terapi kombinasi artemisin dan buah merah dosis $49 \mu \mathrm{L}$ dan $97,5 \mu \mathrm{L}$ lebih rendah dibandingkan dengan kelompok yang diterapi artemisin saja. Diperlukan dosis yang tinggi pada fase kronis untuk mendapat efek buah merah sebagai antioksidan.

Keterbatasan pada penelitian ini tidak dilakukan pemeriksaan produksi $\mathrm{ROI}$ hari ketujuh. Mungkin dosis buah merah yang tinggi diperlukan pada fase awal sebagai imunostimulator dan dosis ini harus dipertahankan unutk mendapatkan efek antioksidannya pada fase akhir. Penelitian yang dilakukan oleh Kulkarni et al., (2003) didapatkan bahwa indikator oksidan dan antioksidan pada penderita malaria Plasmodium falciparum yang telah diterapi klorokuin mulai membaik pada hari ke-3 dan menjadi normal pada hari ke-20.17

\section{Kesimpulan}

Berdasarkan hasil penelitian ini dapat disimpulkan bahwa terdapat peningkatan jumlah sel makrofag yang memproduksi ROI pada mencit yang mendapat terapi kombinasi artemisin dan buah merah dosis $97,5 \mu \mathrm{L} /$ mencit dibandingkan dengan yang diberi artemisin saja pada hari ke-3. Jumlah sel makrofag yang memproduksi ROI pada kelompok yang diterapi kombinasi artemisin dan buah merah dosis $49 \mu \mathrm{L} /$ mencit dan dosis $97,5 \mu \mathrm{L} /$ mencit lebih rendah dibanding yang diberi artemisin saja pada hari ke-5.

\section{Daftar Pustaka}

1. Percário $S$, Moreira DR, Gomes $B A Q$, et al. Oxidative Stress in Malaria. International Journal of Molecular Sciences. 2012; 13(12):16346-16372. doi:10.3390/ijms131216346.

2. Porto BN, Alves LS, Fernández PL, Dutra TP, Figueiredo RT, Graça-Souza AV, Bozza MT. Heme Induces Neutrophil Migration and Reactive Oxygen Species Generation Through Signaling Pathways Characteristic of Chemotactic Receptors.J Biol Chem. 2007; 282:24430-24436.

3. Kannan R, Kumar K, Sahal D, Kukreti S, Chauhan VS. Reaction of Artemisinin with Haemoglobin: Implications For Antimalarial Activity. Biochem. J. 2005; 385:409-418.

4. Akanbi OM, Odaibo AB, Ademowo OG. Effect of Antimalarial Drugs and Malaria Infection on Oxidative Stress in Pregnant Women. African Journal of Reproductive Health. 2010; 14(3):212.

5. Gutteridge JM, and Halliwell B. Antioxidants in Nutrition, Health, and Disease. Oxford: Oxford University Press. 1994. P 1-72.

6. Krinsky $\mathrm{NI}$, Jhonson Ej. Carotenoids Action and their Relation to Health and Disease. Mol Aspect med. 2005; 26(6):459-516.

7. Redaksi Trubus. Seri Praktis: Buah Merah dan Bukti Empiris. Jakarta: Penebar Swadaya. 2005.

8. Tahergorabi Z, Abedini MR, Mitra M, Fard MH, Beydokhti H. "Pandanus conoideus": A Red Fruit with Promising Anticancer Activities. Pharmacognosy Reviews. 2015; 9(18):99-106. doi.10.4103/0973-7847.162108.

9. Blazquez K, Moll K, Ljungstrom I, Petmann, Scherf A, Wahlgren, M. Thawing of Glicerolyte Frozen Parasites 
with $\mathrm{NaCl}$. Methods in Malaria Research $5^{\text {th }}$. Paris: BioMalPar. 2008. pp15.

10. Clemmer L, Martins Y, Zanini M. Arthemeter and Artesunate Show The Highest Efficacies in Rescuing Mice with Late-Stage Cerebral Malaria and Rapidly Decrease Leukocyte Accumulation in Brain. American Society for Microbiology. 2011. p1383-1390.

11. Wu X, Gowda NM, Gowda DC. Phagosomal Acidification Prevents Macrophage Inflammatory Cytokine Production to Malaria, and Dendritic Cells are the Major Source at the Early Stages of Infection: Implication for Malaria Protective Immunity Development. The Journal of Biological Chemistry. 2015; 290(38):23135-23147. doi.10.1074/jbc.M115.671065.

12. Leijh PCJ, Furh RV, Zwet TLV.. In Vitro Determination of Phagocyte and Intracellular Killing by Polymorphonuclear and Mononuclear Phagocyte. In: Weir DM (Editor). Cellular Immunology. London: Blackwell Scientific Publication. 2001. 46.1 - 46.21.

13. Supargiyono. Production, Proliferation, and Functional Activities of Mononuclear Phagocytes during Plasmodium vinkei pitteri Infection in Mice. Thesis. 1993.

14. Nosten F, and White NJ. ArtemisininBased Combination Treatment of Falciparum Malaria. Am J Trop Med Hyg. 2007. 77(Suppl 6):181-192.

15. NDCF. Artemisin New Hope for Malaria Victim. (Online). 2005. www.ndcf.org/reports/Artemisinin.
16. Good MF, $\mathrm{Xu} H$, Wykes $M$, and Engwerda, CR. Development and Regulation of Cell-Mediated Immune Responses to the Blood Stages of Malaria: Implications for Vaccine Research. Annual Review Immunol. 2004; 23:69-99.

17. Kulkarni AG, Suryakar AN, Sardeshmukh AS, and Rathi DB. Studies on Biochemical Changes with Special Reference to Oxidant and Antioxidants in Malaria Patients. Indian Journal of Clinical Biochemistry. 2003;18:136-149.

18. Ahvazi BC, Jacobs $P$, Stevenson MM. Role of Macrophage-Derived Nitric Oxide in Suppression of Lymphocyte Proliferation During Blood-Stage Malaria. (Online).1995.www.jleukbio.org/cgi/conte nt/abstract/58/1/23;

19. Subowo. Imunobiologi..Jakarta: Penerbit Angkasa. 1993. P. 35.

20. Budi IM, dan Paimin FR. Buah Merah. Bogor: Penebar Swadaya. 2005.

21. Hunt N, Kopp M, and Stocker. Free Radicals and Antioxidant in Malaria. In: ASH Ong, and L Pocker (Editor). Lipid Soluble Antioxidants, Biochemistry, and Clinical Application. Switzerland: Birkhasen Verlong. 1992. P. 337-354.

22. Murray. Biokimia Harper. Edisi ke-24. Jakarta: EGC. 1996.

23. Simamora D. dan Fitri L.E. Antioksidan pada Infeksi Malaria. Jurnal Molluca Medica. 2007; II(I):47-56. 